\title{
Clinically Significant Minor Blood Group Antigens amongst North Indian Donor Population
}

\author{
Divjot Singh Lamba, Ravneet Kaur, and Sabita Basu \\ Department of Transfusion Medicine, Block D, Level II, Government Medical College \& Hospital, Chandigarh 160030, India \\ Correspondence should be addressed to Ravneet Kaur; rkbedi15@yahoo.com
}

Received 28 June 2013; Revised 23 October 2013; Accepted 27 October 2013

Academic Editor: Mark R. Litzow

Copyright (c) 2013 Divjot Singh Lamba et al. This is an open access article distributed under the Creative Commons Attribution License, which permits unrestricted use, distribution, and reproduction in any medium, provided the original work is properly cited.

Background. Racial differences in blood group antigen distribution are common and may result in striking and interesting findings. These differences in blood group antigen distribution are important due to their influence on the clinical practice of transfusion medicine. Study Design and Methods. This is a prospective study, involving 1000 healthy regular repeat voluntary blood donors associated with the department. The clinically significant minor blood group antigens of these donors were studied. Results. Out of 1000 healthy regular repeat voluntary blood donors, $93 \%$ were D positive and $2.8 \%$ were K positive. Amongst the Rh antigens, e was the most common (99\%), followed by D (93\%), C (85.1\%), c (62.3\%), and E (21.5\%). Within the MNS blood group system, antigen frequency was $\mathrm{M}(88 \%), \mathrm{N}(57.5 \%), \mathrm{S}(57.8 \%)$, and s (87.5\%). Within the Duffy blood group system, antigen frequency was Fy $(87.3 \%)$ and $\mathrm{Fy}^{\mathrm{b}}$ (58.3\%). Conclusions. This data base will help us to prevent alloimmunisation in young females, pregnant women, and patients who are expected to require repeated transfusions in life by providing them with antigen matched blood. Antigen negative blood can also be made available without delay to already alloimmunized multitransfused patients.

\section{Introduction}

A total of 30 blood group systems are recognized by the International Society of Blood Transfusion (ISBT). Nine blood group systems (ABO, Rhesus, Kell, Kidd, Duffy, MNS, $\mathrm{P}$, Lewis, and Lutheran) are considered to be clinically significant as these are known to cause hemolytic transfusion reactions (HTR) and hemolytic disease of fetus and newborn (HDFN) [1-4].

In developing countries like India only $\mathrm{ABO}$ and $\mathrm{D}$ status of blood donor and recipients are taken into account for compatibility testing. However, the phenotype of clinically significant blood group antigens on the donor red blood cells (RBCs) is required to be known at times when alloimmunization is particularly undesirable, such as in young females, pregnant women, and patients who are expected to require repeated transfusions in life, such as thalassemia or sickle cell disease patients. When selecting blood for transfusion to such patients, it would be useful if we have access to already phenotyped RBCs of donor population so that particular antigen typed blood can be given to such patients to prevent alloimmunization [5]. Furthermore, these are beneficial for already immunized patients if the transfusion is urgent and/or if clinically significant alloantibodies to particular antigen/antigens are present in the patient's serum. In such situations, corresponding antigen negative blood can be given to such recipients without much delay [5].

Racial differences in blood group antigen distributions are common and may result in striking and interesting findings. Very little information is available regarding distribution of various clinically significant minor blood group antigens in northern region of our country. The previous studies are done with limited number donors [6-8]. The present study was done to get an insight of frequency of clinically significant minor blood group antigens amongst regular voluntary blood donors and also to lay foundation of starting a donor database on RBC antigens.

\section{Material and Methods}

This prospective study was conducted in the department of transfusion medicine of a tertiary care hospital after approval 
TABLE 1: Comparison of antigen frequency of Rh subgroup antigens.

\begin{tabular}{lccccc}
\hline Antigens & $\begin{array}{c}\text { Antigen frequency } \\
\text { in total 1000 donors } \\
(\%)\end{array}$ & $\begin{array}{c}\text { Antigen frequency } \\
\text { in Indians by } \\
\text { Thakral et al. [7] }\end{array}$ & $\begin{array}{c}\text { Antigen frequency } \\
\text { in Indians by } \\
\text { Chaudhary et al. [6] }\end{array}$ & $\begin{array}{c}\text { Antigen frequency } \\
\text { in whites [9-11] }\end{array}$ & $\begin{array}{c}\text { Antigen frequency } \\
\text { in blacks [9-11] }\end{array}$ \\
\hline D & $930(93.0 \%)$ & $93.4 \%$ & ND & $85 \%$ & $92 \%$ \\
C & $851(85.1 \%)$ & $84.8 \%$ & $95.2 \%$ & $68 \%$ & $27 \%$ \\
c & $623(62.3 \%)$ & $52.8 \%$ & $69.2 \%$ & $80 \%$ & $96 \%$ \\
E & $215(21.5 \%)$ & $17.9 \%$ & $15.4 \%$ & $29 \%$ & $22 \%$ \\
e & $990(99.0 \%)$ & $98.3 \%$ & $98.1 \%$ & $98 \%$ & $98 \%$ \\
\hline
\end{tabular}

TABLE 2: Comparison of antigen frequency of Rh subgroup antigens in D positive and D negative donors.

Antigens Antigen frequency in D positive donors Antigen frequency in D negative donors

Antigen frequency in total 1000 donors $(\%)$

\begin{tabular}{lccc}
\hline $\mathrm{C}$ & $90.8 \%$ & $10 \%$ & $851(85.1 \%)$ \\
$\mathrm{C}$ & $59.6 \%$ & $98.6 \%$ & $623(62.3 \%)$ \\
$\mathrm{E}$ & $22.8 \%$ & $4.3 \%$ & $215(21.5 \%)$ \\
$\mathrm{e}$ & $98.9 \%$ & $100 \%$ & $990(99.0 \%)$ \\
\hline
\end{tabular}

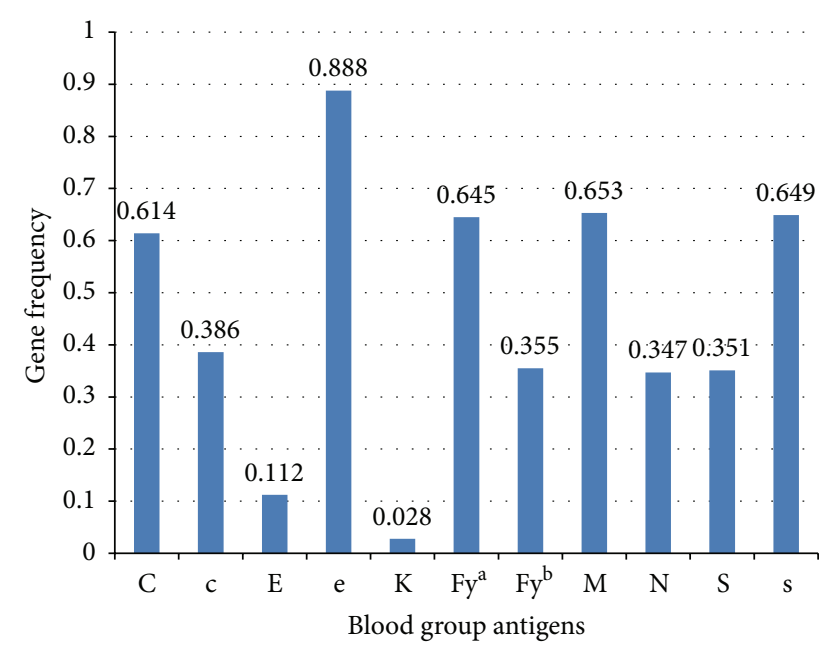

FIGURE 1: Gene frequency of minor blood group antigens.

by the Institutional Ethics Committee and a written informed consent given by the donors.

Blood samples were collected from 1,000 healthy regular repeat voluntary blood donors (who have donated two or more than two times before) between September 2010 and July 2011. Donors to be studied were arranged group-wise, that is, O positive: $34 \%$, A positive: $22 \%$, B positive: $32 \%$, $\mathrm{AB}$ positive: $5 \%$, and negatives: $7 \%$ as per the frequency of these blood groups in North Indian population $[12,13]$. The clinically significant minor blood antigens of the Rh blood group system-C, c, E, and e; Kell blood group system$\mathrm{K}$; Duffy blood system- $-\mathrm{Fy}^{\mathrm{a}}$ and $\mathrm{Fy}^{\mathrm{b}}$; MNS blood group system-M, N, S, and s were studied using DIAMED (BioRad Laboratories, DiaMed Switzerland) gel cards.

\section{Statistical Analysis}

The statistical analysis was carried out using Statistical Package for Social Sciences (SPSS Inc., Chicago, IL, version
15.0 for Windows). Qualitative or categorical variables were described as frequencies and proportions. Proportions for gender were compared using chi-square test. Gene frequencies were calculated using the Hardy Weinberg principle where $p+q=1$ and $p=\{2 \times$ obs $(\mathrm{AA})+\mathrm{obs}(\mathrm{Aa})\} / 2 \times$ $\{\operatorname{obs}(\mathrm{AA})+\operatorname{obs}(\mathrm{Aa})+\operatorname{obs}(\mathrm{aa})\}$; thus $q=1-p$.

\section{Results}

The study included 1,000 healthy regular repeat voluntary blood donors of which 947 were males and 53 were females. The males were significantly more than females with $P<$ 0.001 . The mean age for donors was $35.30 \pm 9.86$. Of the 1,000 blood donors 930 were $\mathrm{D}$ positive and 70 were $\mathrm{D}$ negative. The gene frequency for various blood group systems is depicted in Figure 1.

\subsection{Antigen Frequencies}

4.1.1. Rh Antigens. Amongst Rh antigens, e was the most common (99\%) followed by D (93\%), C (85.1\%), c (62.3\%), and $\mathrm{E}(21.5 \%)$ (Table 1$)$.

4.1.2. Rh Subgroup Antigens in D Positive and D Negative Donors. $98.6 \%$ D negative donors had c antigen and $100 \%$ $\mathrm{D}$ negative donors had e antigen on their red cells. Thus, there is strong association of $\mathrm{c}$ antigen and e antigen with $\mathrm{D}$ negative donors. $\mathrm{C}$ antigen was found to be more associated with presence of $\mathrm{D}$ antigen as compared to its absence $(90.8 \%$ and $10 \%$, resp.) (Table 2 ).

4.1.3. Minor Blood Group Antigen Frequencies. Amongst minor blood group antigens Kell antigen frequency was $2.8 \%$, Duffy $\left(\mathrm{Fy}^{\mathrm{a}}\right)$ 7.3\%, Duffy (Fy $\left.{ }^{\mathrm{b}}\right)$ 58.3\%, M 88\%, N 57.5\%, S 57.8\%, and s $87.5 \%$ (Table 3 ).

\subsection{Phenotype Frequencies}

4.2.1. Duffy Blood Group System. Most common phenotypes in Duffy system were $\mathrm{Fy}^{\mathrm{a}}+\mathrm{Fy}^{\mathrm{b}}+=45.6 \%$ and $\mathrm{Fy}^{\mathrm{a}}+\mathrm{Fy}^{\mathrm{b}}-=$ $41.7 \%$ (Table 4 ). 
TABLE 3: Antigen frequency of clinically significant minor blood group antigens.

\begin{tabular}{|c|c|c|c|c|c|}
\hline Blood group antigen & In 1000 cases (\%) & $\begin{array}{l}\text { Indian study by } \\
\text { Thakral et al. [7] }\end{array}$ & $\begin{array}{c}\text { Indian study by } \\
\text { Chaudhary et al. [6] }\end{array}$ & In whites [6] & In blacks [6] \\
\hline Kell (K) & $28(2.8 \%)$ & $5.56 \%$ & $1.92 \%$ & $0.2 \%$ & $<0.1 \%$ \\
\hline $\mathrm{Fy}^{\mathrm{a}}$ & $873(87.3 \%)$ & $86.8 \%$ & $73.1 \%$ & $17 \%$ & $9 \%$ \\
\hline $\mathrm{Fy}^{\mathrm{b}}$ & $583(58.3 \%)$ & $56.2 \%$ & $53.8 \%$ & $34 \%$ & $22 \%$ \\
\hline $\mathrm{M}$ & $880(88 \%)$ & $75.4 \%$ & $77.9 \%$ & $28 \%$ & $24 \%$ \\
\hline $\mathrm{N}$ & $575(57.5 \%)$ & $61.5 \%$ & $73.1 \%$ & $22 \%$ & $30 \%$ \\
\hline S & $578(57.8 \%)$ & $56.5 \%$ & $63.5 \%$ & $11 \%$ & $3 \%$ \\
\hline s & $875(87.5 \%)$ & $87.4 \%$ & $45.2 \%$ & $45 \%$ & $69 \%$ \\
\hline
\end{tabular}

TABLE 4: Phenotype frequencies of Duffy blood group system.

\begin{tabular}{|c|c|c|c|c|c|c|}
\hline Phenotype & In 1000 cases (\%) & $\begin{array}{l}\text { Indian study by } \\
\text { Thakral et al. [7] }\end{array}$ & $\begin{array}{c}\text { Indian study by } \\
\text { Chaudhary et al. [6] }\end{array}$ & $\begin{array}{c}\text { Indian study by } \\
\text { Nanu and } \\
\text { Thapliyal [8] }\end{array}$ & In whites [9-11] & In blacks [9-11] \\
\hline$F y^{a}+F y^{b}-$ & $417(41.7 \%)$ & $43.9 \%$ & $43 \%$ & $40.8 \%$ & $17 \%$ & $9 \%$ \\
\hline $\mathrm{Fy}^{\mathrm{a}}-\mathrm{Fy}^{\mathrm{b}}+$ & $127(12.7 \%)$ & $13.3 \%$ & $24 \%$ & $16.2 \%$ & $34 \%$ & $22 \%$ \\
\hline$F y^{a}+F y^{b}+$ & $456(45.6 \%)$ & $42.9 \%$ & $30 \%$ & $42.6 \%$ & $49 \%$ & $1 \%$ \\
\hline$F y^{a}-F y^{b}-$ & $0(0 \%)$ & $0 \%$ & $3 \%$ & $0.44 \%$ & $<0.1 \%$ & $68 \%$ \\
\hline
\end{tabular}

TABLE 5: Phenotype frequencies of MN and Ss in MNS blood group system.

\begin{tabular}{|c|c|c|c|c|c|}
\hline Phenotype & In 1000 cases $(\%)$ & $\begin{array}{l}\text { Indian study by } \\
\text { Thakral et al. [7] }\end{array}$ & $\begin{array}{c}\text { Indian study by Nanu } \\
\text { and Thapliyal [8] }\end{array}$ & $\begin{array}{c}\text { In Europeans } \\
{[14,15]}\end{array}$ & $\begin{array}{c}\text { In African } \\
\text { Americans }[14,15]\end{array}$ \\
\hline $\mathrm{M}+\mathrm{N}-$ & $425(42.5 \%)$ & $38.5 \%$ & $42.3 \%$ & $28 \%$ & $26 \%$ \\
\hline $\mathrm{M}-\mathrm{N}+$ & $120(12.0 \%)$ & $24.6 \%$ & $14.6 \%$ & $22 \%$ & $30 \%$ \\
\hline $\mathrm{M}+\mathrm{N}+$ & $455(45.5 \%)$ & $36.9 \%$ & $43.1 \%$ & $50 \%$ & $44 \%$ \\
\hline $\mathrm{S}+\mathrm{s}-$ & $124(12.4 \%)$ & $12.6 \%$ & $10 \%$ & $11 \%$ & $03 \%$ \\
\hline S-s+ & $421(42.1 \%)$ & $43.5 \%$ & $62.1 \%$ & $45 \%$ & $69 \%$ \\
\hline$S+s+$ & $454(45.4 \%)$ & $43.9 \%$ & $26.8 \%$ & $44 \%$ & $28 \%$ \\
\hline$S-s-$ & $1(0.1 \%)$ & $0 \%$ & $1.2 \%$ & $0 \%$ & $01 \%$ \\
\hline
\end{tabular}

4.2.2. MNS Blood Group System. Most common phenotypes were $\mathrm{M}+\mathrm{N}-(42.5 \%), \mathrm{M}+\mathrm{N}+(45.5 \%), \mathrm{S}-\mathrm{s}+(42.1 \%)$, and $\mathrm{S}+\mathrm{s}+$ (45.4\%). (Table 5) The frequency of $\mathrm{M}+\mathrm{N}-\mathrm{S}+\mathrm{s}+, \mathrm{M}+\mathrm{N}+\mathrm{S}+\mathrm{s}+$, and $\mathrm{M}+\mathrm{N}+\mathrm{S}-\mathrm{s}+$ phenotypes was comparable in our study (Table 6).

\section{Discussion}

Besides $\mathrm{ABO}$ and $\mathrm{Rh}$ antibodies, antibodies to other clinically significant antigens are also known to cause HTR, HDFN, or shortened survival of transfused red cells [3]. The knowledge of these clinically significant antigens can help in prevention and appropriate management of pregnancies at risk of HDFN and multitransfused patients with alloimmunization. The frequency of such antigens is available for Caucasians and Black races [9-11, 14, 15]. Very limited information is available on antigen and phenotype frequencies in North India. Other studies are either of small sample size or done in particular blood group donors [6-8]. This is the first study where frequency of clinically significant antigens is studied in 1,000 voluntary blood donors. All the antigen and phenotype frequencies reported in our study were compared with that of
White and Black population [9-11] and with the other studies from North India [6-8].

In the present study the frequency of $\mathrm{D}$ and other $\mathrm{Rh}$ antigens was comparable with that of other studies from the region but was markedly different when compared to Whites and Blacks (Table 1).

The antigen frequencies of Duffy and MNS antigens were comparable to antigen frequencies of other studies in this region but were different from that of white and black population (Table 3 ). The Kell antigen frequency in our study was less (2.8\% versus 5.56\%) compared to those of another study from this region and is higher than that reported in blacks and in whites (Table 3). The difference in Kell antigen frequency in our study compared to the another study from this region may be due to the fact that donor population in our study includes donors of all blood groups as compared to "O blood group" donors in their study. Thus there is a need to perform more studies with a much larger sample size to know more accurately the antigen frequency of Kell antigen in the population of this region.

The phenotype frequencies of Duffy and MNS blood group systems were compared with those of other studies 
TABLE 6: Combined phenotype frequencies of MNSs in MNS blood group system.

\begin{tabular}{|c|c|c|c|c|c|}
\hline Phenotype & In 1000 cases $(\%)$ & $\begin{array}{l}\text { Indian study by } \\
\text { Thakral et al. [7] }\end{array}$ & $\begin{array}{c}\text { Indian study by Nanu } \\
\text { and Thapliyal [8] }\end{array}$ & $\begin{array}{c}\text { In Europeans } \\
{[14,15]} \\
\end{array}$ & $\begin{array}{c}\text { In African } \\
\text { Americans }[14,15]\end{array}$ \\
\hline $\mathrm{M}+\mathrm{N}-\mathrm{S}+\mathrm{s}-$ & $65(6.5 \%)$ & $7.9 \%$ & $5.5 \%$ & $5.7 \%$ & $2.1 \%$ \\
\hline $\mathbf{M}+\mathbf{N}-\mathbf{S}+\mathbf{s}+$ & $208(20.8 \%)$ & $14.8 \%$ & $13.3 \%$ & $14 \%$ & $7 \%$ \\
\hline $\mathrm{M}+\mathrm{N}-\mathrm{S}-\mathrm{s}+$ & $151(15.1 \%)$ & $15.8 \%$ & $22.6 \%$ & $10.1 \%$ & $15.5 \%$ \\
\hline $\mathrm{M}+\mathrm{N}+\mathrm{S}+\mathrm{s}-$ & $50(5 \%)$ & $3.5 \%$ & $4.6 \%$ & $3.9 \%$ & $2.2 \%$ \\
\hline $\mathrm{M}+\mathrm{N}+\mathrm{S}+\mathbf{s}+$ & $201(20.1 \%)$ & $19.6 \%$ & $10.7 \%$ & $22.4 \%$ & $13 \%$ \\
\hline $\mathbf{M}+\mathrm{N}+\mathrm{S}-\mathbf{s}+$ & $204(20.4 \%)$ & $13.9 \%$ & $27.8 \%$ & $22.6 \%$ & $33.4 \%$ \\
\hline $\mathrm{M}-\mathrm{N}+\mathrm{S}+\mathrm{s}-$ & $9(0.9 \%)$ & $1.3 \%$ & $1.2 \%$ & $0.3 \%$ & $1.6 \%$ \\
\hline $\mathrm{M}-\mathrm{N}+\mathrm{S}+\mathrm{s}+$ & $45(4.5 \%)$ & $9.5 \%$ & $3.5 \%$ & $5.4 \%$ & $4.5 \%$ \\
\hline $\mathrm{M}-\mathrm{N}+\mathrm{S}-\mathrm{s}+$ & $66(6.6 \%)$ & $13.9 \%$ & $9.3 \%$ & $15.6 \%$ & $19.2 \%$ \\
\hline $\mathrm{M}-\mathrm{N}+\mathrm{S}-\mathrm{s}-$ & $0(0 \%)$ & $0 \%$ & $0.3 \%$ & $0 \%$ & $0.7 \%$ \\
\hline
\end{tabular}

from the region and with that of white and black population (Tables 4, 5, and 6). These results support the fact that there is variation in the distribution of antigens in the Duffy and MNS blood group system even in North Indian population [7]. Thus there is a need to perform more studies with a much larger sample size to know more accurately the phenotype frequency of Duffy and MNS antigens in the population of this region.

The beta thalassemia carrier rate in India is around 3$7 \%$ with higher frequency in northwest India. Approximately 10,000 thalassemia major cases are added each year [16]. The prevalence of alloimmunization in multitransfused patients in India is approximately $3-10 \%[17,18]$. This study has provided us with donor database of regular repeat voluntary blood donors with known antigenic profile which is referred to, to provide antigen matched blood to young females, pregnant women, and patients who are expected to require repeated transfusions in life. Antigen negative blood is also being provided to already alloimmunized multitransfused patients. This has helped us to prevent alloimmunisation in these groups of patients and prevent already alloimmunised patients from further alloimmunisation.

\section{Limitations}

Kidd antigen evaluation in donors was not done due to cost constraints.

\section{Conflict of Interests}

No author has a direct financial relation with the commercial identities mentioned in the paper that might lead to conflict of interests for any of the authors.

\section{References}

[1] G. Daniels, L. Castilho, W. A. Flegel et al., "International society of blood transfusion committee on terminology for red blood cell surface antigens: macao report," Vox Sanguinis, vol. 96, no. 2, pp. 153-156, 2009.
[2] E. Smart and B. Armstrong, "Blood group systems," International Society of Blood Transfusion Science Series, vol. 3, pp. 6892, 2008.

[3] J. Poole and G. Daniels, "Blood group antibodies and their significance in transfusion medicine," Transfusion Medicine Reviews, vol. 21, no. 1, pp. 58-71, 2007.

[4] J. M. Bowman, "Intrauterine transfusion," in Anderson and Ness Scientific Basis of Transfusion Medicine: Implications for Clinical Practice, K. C. Anderson and P. M. Ness, Eds., pp. 403-420, WB Saunders, Philadelphia, PA, USA, 2nd edition, 1994.

[5] B. Diedrich, J. Andersson, S. Sallander, and A. Shanwell, "K, Fya and Jka phenotyping of donor RBCs on microplates," Transfusion, vol. 41, no. 10, pp. 1263-1267, 2001.

[6] R. K. Chaudhary, J. S. Shukla, and V. Ray, "Minor Red cell antigens in north Indian blood donor population," Indian Journal of Hematology and Blood Transfusion, vol. 21, pp. 34-35, 2003.

[7] B. Thakral, K. Saluja, R. R. Sharma, and N. Marwaha, "Phenotype frequencies of blood group systems (Rh, Kell, Kidd, Duffy, MNS, P, Lewis, and Lutheran) in North Indian blood donors," Transfusion and Apheresis Science, vol. 43, no. 1, pp. 17-22, 2010.

[8] A. Nanu and R. M. Thapliyal, "Blood group gene frequency in a selected north Indian population," Indian Journal of Medical Research, vol. 106, pp. 242-246, 1997.

[9] M. E. Brecher, Technical Manual, American Association of Blood Banks, Bethesda, Md, USA, 15th edition, 2005.

[10] G. Daniels, Human Blood Groups, Blackwell Science, Oxford, UK, 2nd edition, 2002.

[11] D. M. Harmening, Modern Blood Banking and Transfusion Practices, FA Davis Company, Philadelphia, PA, USA, 5th edition, 2005.

[12] N. A. Bhat, M. A. Kammili, S. A. Kadla, and A. Nafae, "Frequency of blood groups in donors and recipients," The Indian Practitioner, vol. 52, pp. 160-164, 1999.

[13] J. A. Latoo, N. A. Masoodi, N. A. Bhat, G. Q. Khan, and S. A. Kadla, "The ABO and $\mathrm{Rh}$ blood groups in Kashmiri population," Indian Journal for the Practising Doctor, vol. 3, no. 2, 2 pages, 2006, http://www.indmedica.com/journals.php.

[14] T. E. Cleghorn, "MNSs gene frequencies in English blood donors," Nature, vol. 187, no. 4738, p. 701, 1960.

[15] R. R. Race and R. Sanger, Blood Groups in Man, Blackwell Scientific Publications, Oxford, UK, 4th edition, 1975.

[16] I. Panigrahi and R. K. Marwaha, "Common queries in thalassemia care," Indian Pediatrics, vol. 43, no. 6, pp. 513-518, 2006. 
[17] B. Thakral, K. Saluja, N. Marwaha, and R. R. Sharma, "Red cell alloimmunization in a transfused patient population: a study from a tertiary care hospital in north India," Hematology, vol. 13, no. 5, pp. 313-318, 2008.

[18] R. Gupta, D. K. Singh, B. Singh, and U. Rusia, "Alloimmunization to red cells in thalassemics: emerging problem and future strategies," Transfusion and Apheresis Science, vol. 45, no. 2, pp. 167-170, 2011. 


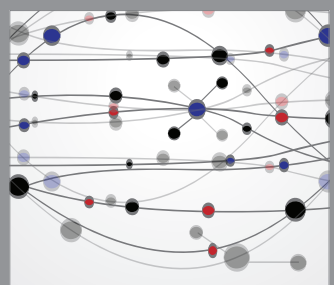

The Scientific World Journal
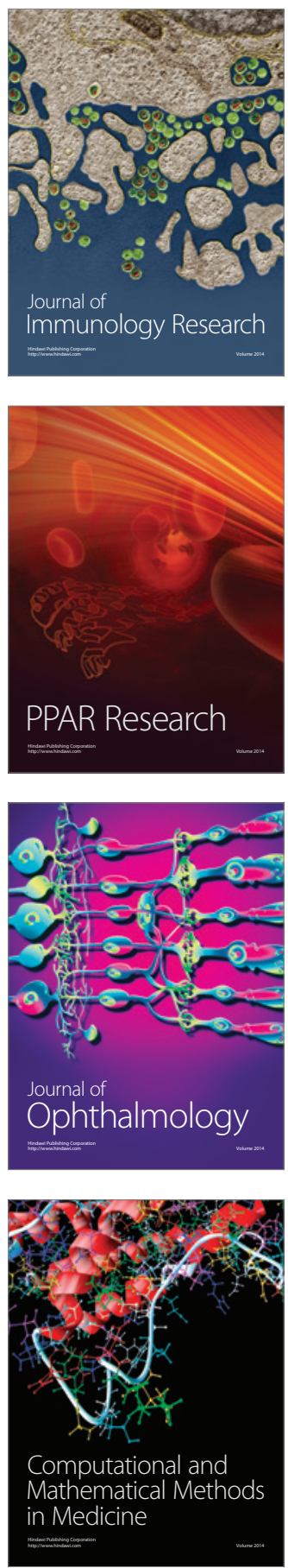

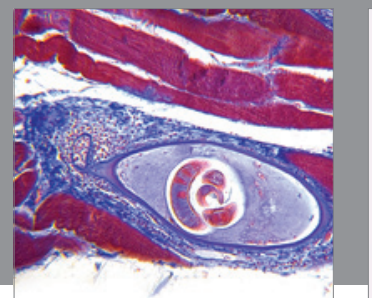

Gastroenterology

Research and Practice
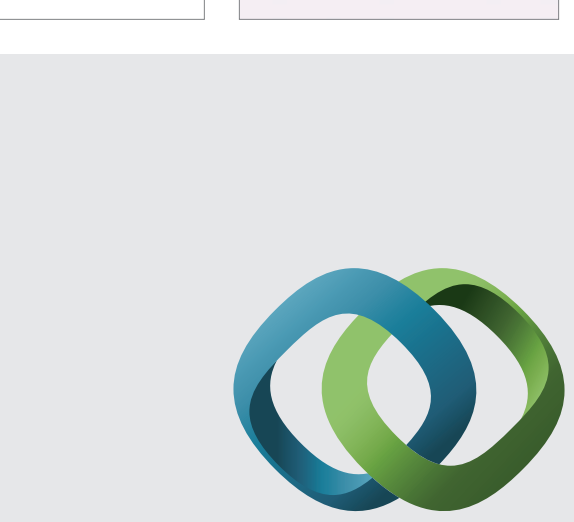

\section{Hindawi}

Submit your manuscripts at

http://www.hindawi.com
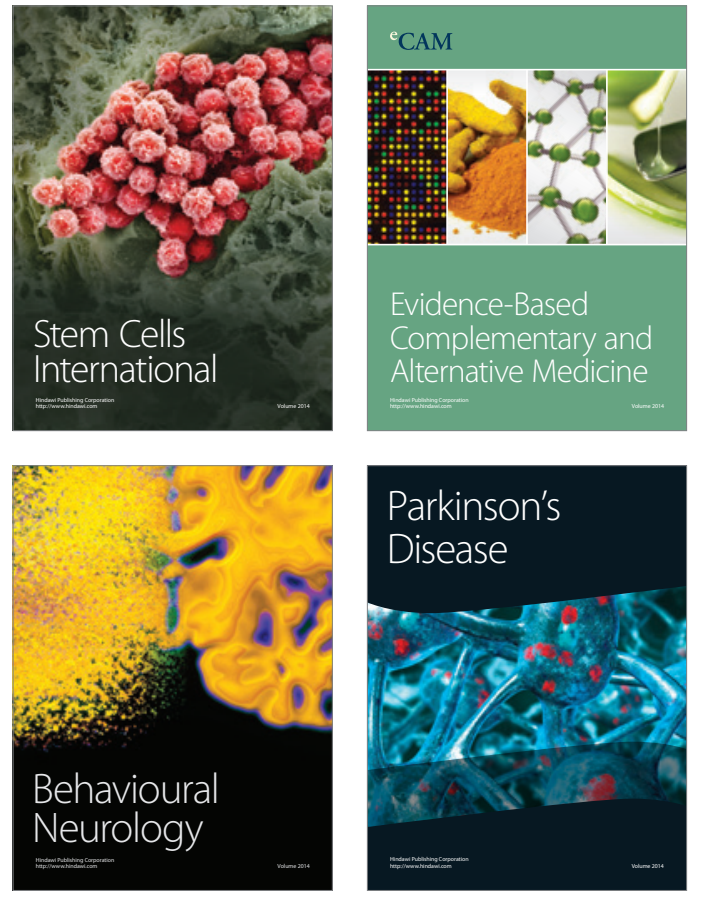
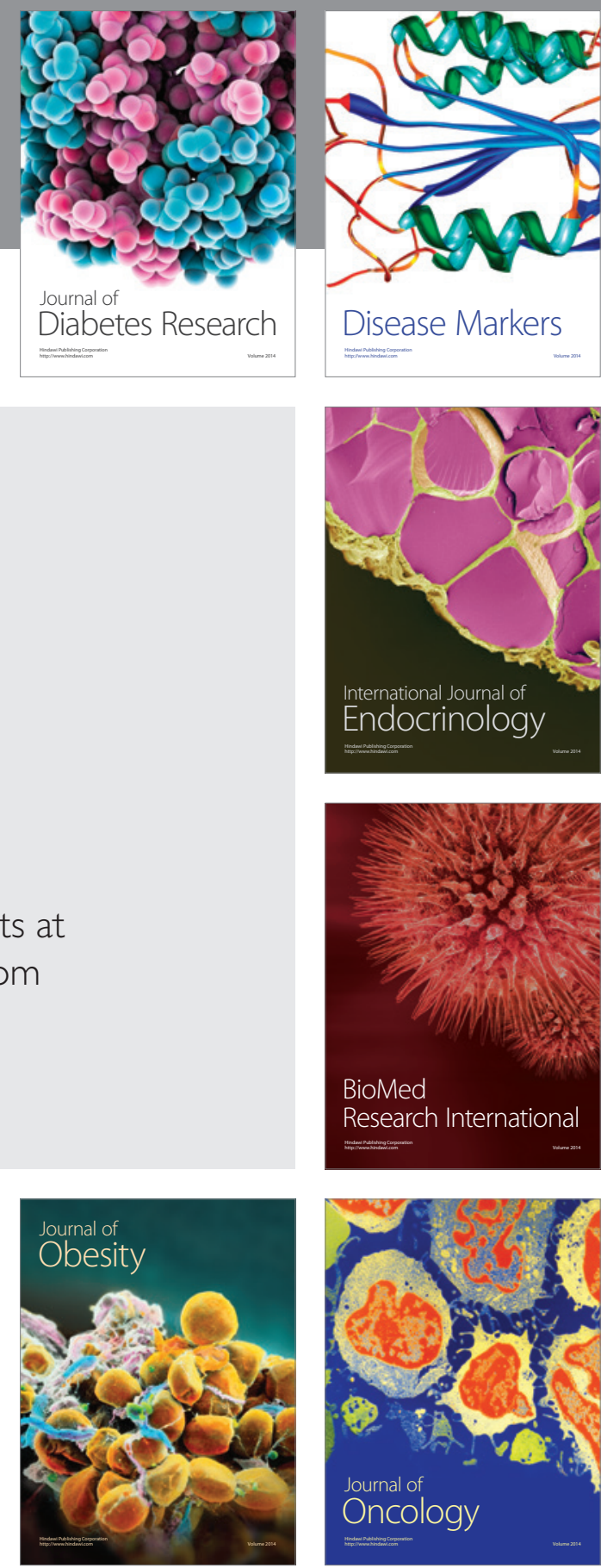

Disease Markers
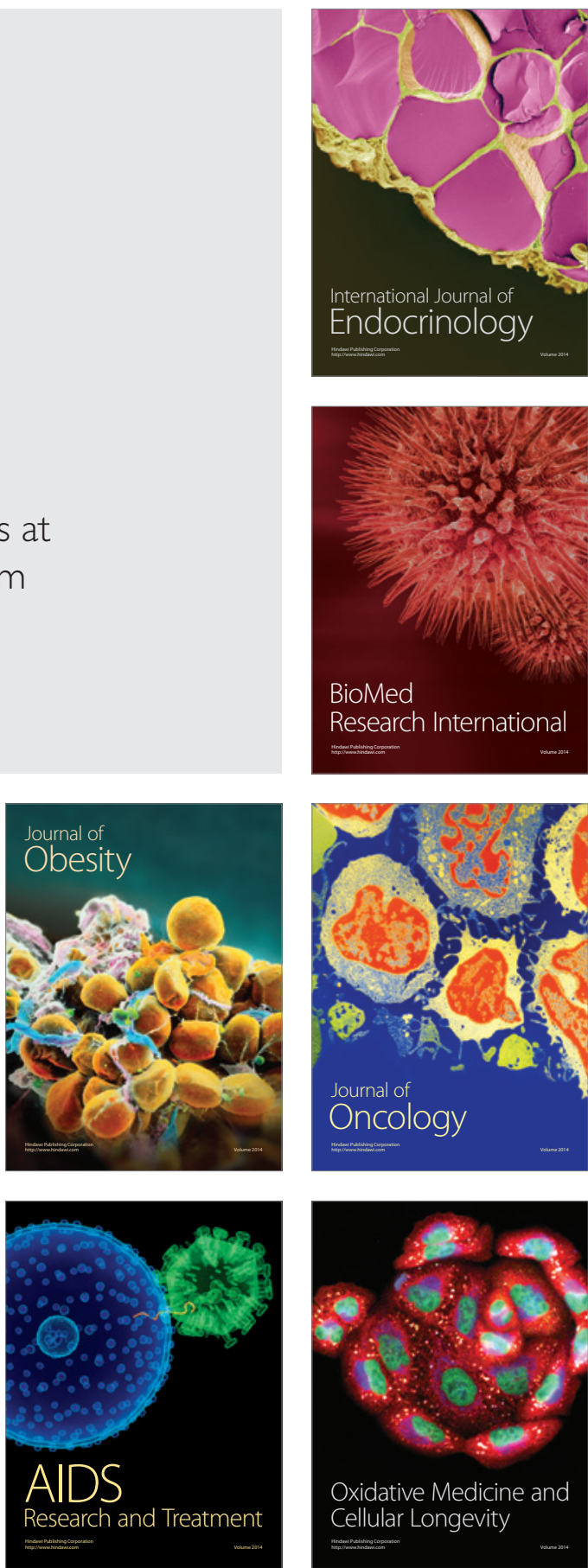